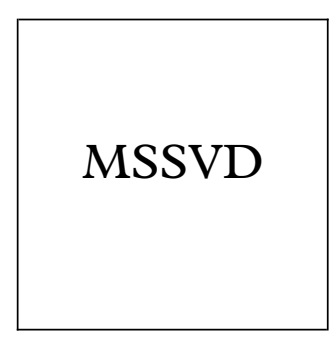

\title{
A short history of the Medical Society for the Study of Venereal Diseases on its 75th birthday
}

\author{
The Ninth Harrison Lecture
}

R S Morton

\section{Introduction}

As we celebrate our 75 th birthday the eponymous title of the lecture series reminds us of the lifetime dedication given to our specialty by Col L W Harrison, DSO. He was the son of a Lancashire general practitioner and qualified in medicine in Glasgow in 1897. Two years later he joined the Army Medical Corps and served in the South African war and in the first world war. He tells us ${ }^{1}$ that his peacetime training was in bacteriology. His first contact with venereal diseases was in 1909 when he was posted to the Military Hospital at Rochester Row in London. The staff there concerned itself not only with clinical care of VD patients but with research and instruction of all grades of personnel. Harrison's contribution at this time was to establish standards in diagnosis.

In 1915, Harrison was called upon to run a 250 bedded special unit in a military hospital at Le Havre. Soon the unit had grown to 3000 beds.

In 1919, with his administrative and organisational skills recognised, he was invited to establish a VD clinic at St Thomas's Hospital, London and to be adviser to the Ministry of Health. The Ministry was then more than two thirds of the way through establishing the nationwide network of clinics as recommended by the Royal Commission in $1916 .^{2}$

\section{The birth of the MSSVD}

The supportive liaisons developed in those captivated by the new national and clinically appropriate approach to the venereally infected called for something more formal. The first initiative for the establishment of an independent forum where the new specialty's many and varied problems could be discussed, recorded, and reported came originally from a Dr David Watson then in charge of VD clinics in Glasgow. After wide discussion it was agreed to present a report to a meeting of all interested parties. Thus, on the 9 June 1922 at the Royal Society of Medicine a proposal "That a Medical Society for the Study of Venereal Diseases be established" was carried unanimously. A 10 person provisional committee called the first annual general meeting at the Royal Society of Medicine in London on 31 July 1922. Officers and council members were appointed. Six ordinary general meetings were to be held per year. This consensus based foundation was to prove successful. ${ }^{3}$

\section{The domestic scene}

One of the early topics discussed by council was the establishment of a society or specialist journal. The first editorial declared ${ }^{4}$ that the journal's aim was to foster the scientific outlook through harmony between clinicians and laboratory workers.

The first volume contained 33 articles. The emphasis was on treatment of gonorrhoea and syphilis. Seven of the 33 articles had been presented at the society's regular meetings. The discussion which followed each presentation was reported in detail.

The MSSVD was established in 1922 and table 1 shows the caseload figures for the years before and after that year.

Doctors with wartime experience of venereal disease as well as many others welcomed the new service. These men and women, through the MSSVD and its journal, were to reach consensus on many topics concerning diagnosis, treatment, and follow up. Thus disparities in standards of care were soon minimal. Efforts at disease control were augmented by case finding in syphilis. Routine testing of inpatients in both general and mental hospitals as well as antenatal clinics increased throughout the country in the 1920 s and 1930 s. The arrival of the sulphonamides in the mid 1930s revolutionised the treatment of gonorrhoea and also gave hope of improved control of that infection.

An opportunity to survey council minutes for the years 1949-89 and the published annual reports of honorary secretaries of the society shows the vast array and variety of topics dealt with. These cover rule changes, the introduction in 1973 of the term "sexually transmitted diseases" in lieu of "venereal diseases", the design of new clinics, and above all the professional education of all grades of health workers in the specialty.

In 1963 the society established a library, now housed at the Royal Society of Medicine in London. Dr David Oriel is the society's librarian.

\section{National developments}

THE 1940s

Since the first world war the army had an adviser in venereology. In 1939 he was Dr T E Osmond who had served with Col Harrison as pathologist in Le Havre. As Brigadier Osmond he proved himself beyond question. Every area of command had a VD adviser at home and abroad. Training courses for young medical officers were promptly established. Thus the forces' needs were anticipated and met.

At home in wartime the paper shortage obliged the publishers of the journal to use smaller print. Society meetings were arranged for Saturday afternoons in London. The 
Table 1 The caseloads and costs for 1921 and 1923

\begin{tabular}{lll}
\hline & 1921 & 1923 \\
\hline New patients (NP) & 170607 & 162412 \\
Total attendances (TA) & 1612952 & 1605617 \\
Ratio TA:NP & $9.4: 1$ & $9.8: 1$ \\
Inpatient days & 159102 & 168133 \\
Costs & $1921 / 22 £ 452000$ & $1922 / 23 £ 390000$ \\
\hline
\end{tabular}

council, with the end of hostilities, arranged for all senior serving officers and members of the MSSVD to report and publish their experiences.

Wartime prompted discussion about contact tracing and public education. As regards the first, the result was the establishment of the "Tyneside experiment" in 1943. A society meeting in 1945 discussed like endeavours. Three social workers presented reports and a record 16 members participated in the discussion. A report on the successes of the Tyneside scheme was published in $1972 .{ }^{5}$

Nationally directed public education endeavours via bill posters and pamphlets were augmented by Dr Laird's book of $1943 .^{6} \mathrm{It}$ supplemented MacLachlan's textbook on venereal diseases ${ }^{7}$ the first to detail the use and benefits of penicillin. To a third society member, Dr A H Harkness, distinction came in 1950 with his publication "Non-gonococcal urethritis". 8

In the same year, Dr Robert Lees, one of the senior ex-service venereologists active in preNational Health Service (NHS) discussions, gave his address as MSSVD President. He brought to members' notice the Ministry of Health's first circular to the NHS's newly appointed regional hospital boards. It read: "The diagnosis and treatment of VD constitutes a separate clinical specialty and should not be left to become a minor interest of specialists in other fields such as dermatology". (RHB 1 (48).)

Comparable status with all other hospital specialties and specialists was thus secured.

Post-war British society was preoccupied with establishing marriages and families. Money was short. This social state of stability gave control measures and the advent of penicillin an unsurpassed opportunity for progress in personal and public health terms. Within four years there is clear evidence of control and in a society meeting at Oxford in 1954 there was talk of syphilis and gonorrhoea as "dying diseases".

THE 1950s

In 1952 the society set up a research committee, the British Co-operative Clinical Group (BCCG). ${ }^{9}$ During a quarter century's secretaryship by Dr R R Willcox the BCCG turned out more than 20 important articles and reviews.

One piece of research calls for special attention. It started in the late 1950s with two reports. One described Reiter's disease in two cousins and the other in two brothers. The final outcome came after more than a decade. After repeated discussions in council, centred mainly on questions of confidentiality, it was agreed to seek the cooperation of the mobile unit of the
Empire Rheumatism Council (complete with $x$ ray and laboratory facilities) to visit and examine the families of men with Reiter's disease who volunteered their cooperation through MSSVD members. In April 1965 the preliminary results were presented to a meeting of the society. They supported the idea of a familial element. Brewerton et al's paper of 1973 described the association of Reiter's disease with the histocompatibility antigen HLA/B27. ${ }^{10}$ The et al included the name of a senior member of the society, Dr J K Oates. The completed families study by the Empire Rheumatism council and the BCCG was published in $1974 .{ }^{11}$

\section{THE $1960 \mathrm{~s}$}

Increases in incidence of gonorrhoea were joined by similar trends in non-gonococcal urethritis and, before the 1960s ended, by mounting prevalence rates of what became known as the second generation of sexually transmitted diseases. Pressure on clinic staffs began to rise. council appointed a subcommittee to prepare evidence of the need for improved medical education in venereology. The approved report was forwarded to the Royal Commission on Medical Education. It was some years before the contracts of NHS hospital consultants with teaching responsibilities showed one session per week to be devoted to teaching. The establishment of postgraduate diploma courses first in Liverpool and later in London was another major advance.

In research terms, the highlight of the $1960 \mathrm{~s}$ was the discovery in 1964 of the genitourinary Chlamydia trachomatis by Dr Eric Dunlop and his team at the London Hospital.

The mid 1960s saw the beginning of qualitative changes in the increasing case loads. It became clear that for many people the arrival of the contraceptive pill made the "permissive society" a practical reality. The male:female ratios changed. This was most notable in gonorrhoea where the usual ratio of male:female ratio of 3:1 grew towards unity. As the decade advanced it was clear that pressure of numbers on clinic staffs was becoming unsustainable. Two senior members of the society published a detailed analysis of the situation in $1970 .^{12}$

The trends of the 1960s prompted fresh discussion about contact tracing. In 1968 a working party of society members under the chairmanship of the ministry adviser, $\mathrm{Mr}$ Ambrose King, was instrumental in improving communication and cooperation between health workers in treatment centres both at home and abroad. The working party also prompted changes in the law (The National Health Service [Venereal Diseases] Regulations, 1968) so that health workers are clearly protected from charges of slander or libel provided they act in good faith and strictly confidentially on the data available to them. In addition, clinics were obliged to report the results of their contact tracing endeavours concerning syphilis and gonorrhoea. The hope was that this early attempt at auditing would provide a record of improvements. Alas, after 20 years no feedback of the data has been provided. 
THE 1970 s

The new decade opened with discussions prompted by "Crisis in venereology". ${ }^{12}$ Such a clear case of need resulted in an immediate and substantial increase in the number of trainee medical posts. Within a few years formal postbasic training courses for clinic nurses were made available in three centres. With the support of the MSSVD nurses undertaking contact tracing, health education, and counselling also had recognition and improved training facilities.

Health education of the public of all ages by paperbacks, booklets, and films started in the 1960s, and continued into the 1970s. Two reports give details. ${ }^{1314}$

The 1974 annual general meeting of the society approved a proposal from council that the name of the specialty be changed from venereology to genitourinary medicine.

In the mid 1970 s came with the establishment of the Joint Commission on Higher Medical Training (JCHMT) and the obligation of all associated specialist advisory committees (SAC) to inspect and authorise departments suitable for postgraduate training and so ensure through regular visits that training proceeds satisfactorily for all concerned. Delegates to the JCHMT and the specialty's SAC are appointed by the MSSVD Council.

Successfully trained specialists are registered as such.

\section{THE $1980 \mathrm{~s}$}

The 1980s brought calls for action. Staffing needs were again a problem. Added to the ever growing problems associated with the "second generation" of STDs came the arrival of HIV/ AIDS. As an outcome of discussions a genitourinary medicine committee was formed with Professor Michael Adler as honorary secretary. Its first remit was to tackle staffing problems. It has also made the approach to HIV/AIDS case care and control sensitive and sensible.

In 1988 a Department of Health working party produced the Monks Report. ${ }^{15}$ It dealt with a wide range of topics from equipment of clinics, through appointment systems, to laboratory support. The report's clear conclusion was that a sounder, forward looking basis was needed to ensure continuing high quality personal care of patients as well as effective levels of public health control. Useful responses followed.

THE 1990s

In 1990 an updated guidance note on the planning and design of modern clinics was published. ${ }^{16}$ This was followed a year later by the chief medical officer's Health of the Nation which gave the specialty specific objectives.

In addition, in 1992, there were two well timed editorials in the journal which since 1985 has been called Genitourinary Medicine rather than the British Fournal of Venereal Diseases. One editorial dealt with the questions involved in auditing ${ }^{17}$ and the other the details of the CMO's challenge. ${ }^{18}$ The objectives were soon achieved.
Throughout the years, staffing clinics to match the number of patients has never been easily attained. ${ }^{19}$ One welcome feature since the inception of the service has been its popularity with women doctors. From the earliest days they have made noteworthy contributions. Dr Elizabeth Keighley's observation that cancer of the cervix was common in prostitutes has led through recognition of its sexually transmitted element to active prevention. No less the involvement of Drs Elizabeth Rees and Pat Munday in regular research has done much to unravel some of the mysteries of chlamydial infection. Not least when there was talk of abandoning routine antenatal testing for syphilis, it was Dr Jennifer Clay's BMF editorial that brought discussion to an immediate and sensible end. ${ }^{20}$ The successors of these women are proving no less distinguished.

Like staffing, medical training continues to demand constant attention. The society's education subcommittee reported in detail in October 1994 on "Undergraduate training". The views of individual contributors to the discussions behind the document were published in $1996 .{ }^{21}$ Continuing medical education (CME) for postgraduates was dealt with editorially in the same year. ${ }^{22}$

\section{International influences}

As long ago as 1948 the council of the MSSVD resolved to request the World Health Organisation (WHO), as a matter of urgency, that all countries be encouraged to establish a VD society comparable to the MSSVD in status and constitution. The outcome was the International Union against Venereal Diseases (IUVDT). Several Britishers over the years have held high office in the union.

Several society members have undertaken short and long term assignments on behalf of the WHO in third world countries. The diploma courses continue to be popular with overseas postgraduates. Dr S M Laird was editor of our journal for 15 years from $1950 . \mathrm{He}$ sought and published many reports from overseas. In addition, the society decided to hold its spring meetings on the European continent in alternate years. That we are ready to share our national advantages has long been reflected in the MSSVD membership. As long ago as 1977 the honorary secretary's annual report noted that of 570 members no less than 239 were from overseas. ${ }^{23}$

\section{Coda}

In reviewing the internal workings, national developments, and overseas influences of the MSSVD, what has impressed me most is the high percentage of members who have involved themselves with the day to day workings and the development of adaptations to meet a variety of changes. The research efforts of many, individually, jointly, and/or by consensus is no less remarkable.

I count it as one of the great privileges of my professional life to have spent half a century in such good company.

Shortened version of paper delivered at the Spring Meeting of the MSSVD at Oxford on 2-6 July 1997. 
1 Harrison LW. Some lessons learnt in fifty years' practice in venereology. Br 7 Vener Dis 1954;30:184-90.

2 King AJ. The First Harrison Lecture. The life and times of Colonel Harrison. Brf Vener Dis 1974;50:391-403.

3 Harrison WL, Forgan R. History of the MSSVD with a history of the Scottish branch. Br F Vener Dis 1961;37:2-32.

4 Editorial. Br F Vener Dis 1925;3:35-50.

5 Wigfield AS. Twenty-seven years of uninterrupted contact tracing: the Tyneside scheme. Brf Vener Dis 1972;48:37-50. Laird SM. Venereal disease in Britain. Harmonsworth: Penguin Books, 1943.

7 MacLachlan AEW. Venereal diseases. 1st edn, 1944; 2nd edn, 1945. Edinburgh: Livingstone.

8 Harkness AH. Non-gonococcal urethritis. Edinburgh: E \& S Livingstone, 1950 .

9 The British Co-operative Clinical Group. Br $\mathcal{f}$ Vener Dis 1952;28:101.

10 Brewerton DA, Caffrey M, Nichols A, et al. Reiter's disease and HLA27. Lancet 1973;ii:996-9.

1 Lawrence JS. Family survey of Reiter's disease $B r q$ Vener Dis 1974;50:140-5.

12 Morton RS, Catherall RD. Crisis in venereology. $B M \mathcal{F}$ 1970;3:699-702.

13 Morton RS. Possible new approaches to the public in venereal diseases education. WHO seminar working document. Geneva: WHO Document, 1HF/VDT/1974/329.
14 Rowntree F St D. Health education. In: Morton RS, Harris JRW, eds. Recent advances in sexually transmitted diseases. Edinburgh: Churchill Livingstone, 1975; Chapter 46: 388 402

15 The Monks Report. Report of the working group to examine work loads in genitourinary medicine clinics. London: Department of Health, 1988.

16 Thin RNT, Lamb J. Guidance for planning and design of genitourinary medicine clinics. Genitourin Med 1990;66: 393-8.

17 Mercey D. Clinical audit in genitourinary medicine: why, who, what, how, and when? Genitourin Med 1992;68:205-6.

18 Scouler A, Adler MW. "The health of the nation": a challenge for genitourinary medicine. Genitourin Med challenge for

19 Allen J, Hogg D. Work roles and responsibilities in genitourinary medicine clinics. London: Policy Studies Institute, 1993.

20 Clay J. Antenatal screening for syphilis. BMF 1989;299:40910.

21 Cowan FM, Dhar J, Patel R, et al. Undergraduate teaching of genitourinary medicine in Britain - what are the issues? Genitourin Med 1996;72:6-8.

22 Cowan FM. An introduction to the series on continuing medical education. Genitourin Med 1996;72:236.

23 Schofield CBS. Annual Report. Br 7 Vener Dis 1977;53: 398. 